\title{
COMPARISON OF METHODOLOGICAL APPROACHES IN THE CREATION OF TENDER CALCULATIONS IN METAL SHEET PARTS AND WELDED CONSTRUCTIONS PRODUCTION
}

\author{
${ }^{1}$ Dalibor LABOUNEK, ${ }^{2}$ Kamila JANOVSKA \\ VSB - Technical University of Ostrava, Ostrava, Czech Republic, EU, \\ 1dalibor.labounek.st@vsb.cz, ${ }^{2}$ kamila.janovska@vsb.cz
}

https://doi.org/10.37904/metal.2021.4282

\begin{abstract}
The paper presents a comparison of methodological approaches to creating tender calculations in engineering companies focused on the production of metal sheet parts and welded constructions. The compared methodologies of tender calculations are divided into a manual conventional approach and an automated approach. The conventional methodology is based on a practical approach to the creation of tender calculations by specific companies. The automated approach is performed through a prototype of the online calculation application Aurendi. The calculation is performed by both mentioned approaches on selected types of drawings of metal sheet parts and welded constructions to achieve the relevant research results. The drawing documentations were carefully selected to require a wide range of technological operations necessary for producing the parts. The list of key technological operations is based on laser cutting, bending on a bending press, straightening, welding, grinding, surface treatment and other smaller workshop operations. Raw materials, fasteners and logistics operations associated with the production of the parts are included in the price of purchased items. A crucial point in the creation of the calculation is a selection and acquisition of a suitable type of material considering the prescription in the drawing documentation. The subject of the research is to determine the percentage of time savings using the automated methodology offered by the Aurendi in comparison with the conventional approach. A part of the research output is the time data necessary for creating the tender calculation as well as the calculated prices for both compared approaches.
\end{abstract}

Key words: Tender calculations, mechanical industry, metal sheet parts, welded constructions, pricing

\section{INTRODUCTION}

According to the definition of the Oxford Advanced Learner's Dictionary, the word "Automation" means use machines and computers for work previously done by men. [1] Metal sheet part producers have to take into consideration different procedures to distinguish themselves from their competitors in the market. Offering customized, top-quality products at the lowest price possible is the main goal in order to stay in the market. The production cost has to be known, so the producer can set the price as competitive as possible. It is important to have an appropriate information system for production tracking and evidence in company [2]. After the manufacturing process, a detailed report can be collected in order to determine the cost of the final product through after-calculation. However, quite often an estimate of the production cost is required, prior to the actual production of that part. The production cost, therefore, has to be estimated within as precise as possible accuracy range, although all necessary detailed information is not known yet. To surpass this lack of detailed information, cost-estimation techniques are used by producers to assess the cost within a certain accuracy range. Different cost estimation approaches resulting in three main methods can be found [3]: 
- Variant-based cost estimation: product cost estimation is based on the actual cost of similar products manufactured already. Decision-making based on the partial similarity of the products produced before is not that exact and rather subjective, therefore inclinable to mistakes [4].

- Generative cost estimation: Estimation procedure based on the detailed analysis of different production processes. For each particular process, the cost is assigned, therefore this kind of cost estimation is mainly based on process planning $[5,6]$.

- Hybrid cost estimation: This method is executed in situations where the final product is completed from different parts and where some of those parts are in different stages of development. As a result, detailed information will be available on some products, while others are still in the early stages of development, without further information. Generative methods can be used for parts with available data. For those parts that are still in the initial stages, variant-based methods are used [7].

The determination of the selling price for a product must be considered from the design of the part, therefore it is important to provide designers with tools and methods for assessing product costs during the early stages of the design process when there are the necessary degrees of freedom to change critical product features towards economic savings [8]. The preparation of tender calculations in engineering companies is based on basic concepts from the field of economics and the market environment. The term market in the economy means any system of buying and selling. It is a coordinating mechanism that puts together separate plans of individual entities trying to sell and buy the goods. The market can take various forms: physical, virtual, product and service markets, production invoice markets, etc. The business relationship begins with a potential customer's demand from a potential supplier. This is the relationship between the different prices of goods and the quantities that consumers want and are able to buy at these prices over a period of time. This relationship can be represented as a demand table or demand curve. The quantity that consumers intend to buy at a given price over a period of time is called the quantity demanded. The setting of tender prices is governed by the law of demand, which is described as follows. Under otherwise unchanged circumstances, with the growth of the price, the demanded quantity will decrease and, conversely, with the decrease of the price, the demanded quantity will increase. In response to demand, potential sellers respond with supply, which is the relationship between the different prices of goods and the quantity offered by sellers over a period of time. Similar to demand, supply can be represented by a supply table or a supply curve. The quantity of product offered is the quantity that the manufacturer plans to sell in a given period of time at a given price [9]. The basic criterion in any tender is the price, which indicates how much money we have to give for a particular good or service [10]. In order to determine the price properly, it is necessary to know the competitive environment and the importance of competition. Competition is defined as rivalry between sellers or buyers of the same goods, i.e. as competition across the market. It means a clash of supply and demand [11].

\section{THE METHODOLOGY BASES}

The aim of this paper is to compare two different methodological approaches in the calculation of tender calculations.

\subsection{Research of conventional methodological approach in practise}

The essential for the correct calculation of the tender calculation for sheet metal parts and welded constructions is the demonstrable experience of a professional familiar with the engineering environment of manufacturing companies. The professionals must be knowledgeable of production processes to such an extent that they are able to reliably calculate the tender calculation so that the resulting tender price is competitive with other tender and at the same time calculated to ensure the company's profit. Basic points that must be considered when calculating the tender calculation are price of material, cost of laser cutting, bending costs (bending press), welding, grinding, surface finishing, other workshop operations and cooperation (this point includes a wide 
range of possible technological operations depending on the nature of each part calculated. With regard to the significantly lower frequency of specific workshop operations and their variability, for the research of percentage time savings, this point will be characterized as a set of partial workshop operations), handling and packaging, transport, and margins.

Material price: The price of the material is available from the established suppliers of metallurgical materials of each company on request from a sales representative and offered based on the current trend in the market of materials and the required quantity.

Laser cutting costs: This point can be solved in two ways concerning the situation in each company if it owns the technology or uses it through cooperation with a partner company that owns the technology.

Own technology - the employee submits the tender documentation for automated calculation through the software supplied with the technology and thus obtains the exact time required for the production of the part. Technology of the subcontractor - the employee sends the materials for production to his subcontractor and receives feedback with a specific price offer for subcontracting (for the research, a variant of the company's own technology will be considered due to other incoming inaccuracies in the meaning of the necessary time allowance for partner companies to obtain a subcontract).

Bending costs: At this point, we will also assume ownership of the technology by the company. The cost for the technology on a bending press can be calculated by subtracting the amount and complexity of bends on the part from the drawing documentation. Furthermore, the size and weight of each part must be taken into account and these inputs should be reflected in the final price calculation.

Welding: The calculation of the technological part of welding is estimated based on the regulation on the drawing documentation and the length of the weld.

Grinding: When processing sheet metal parts and welded structures, grinding is intended as a basic surface treatment performed to unify the surface after welding. The costs of the grinding operation are estimated through the welding parameters prescribed in the drawing documentation.

Surface finish: At this point, the surface treatment means the requirement for galvanizing, blasting, or painting in the case of processing carbon steel parts, or design grinding, ballotine blasting or painting in the case of processing stainless steel parts and anodizing aluminum.

Other workshop operations and cooperation: The key point for the research is not a complete analysis of all possible workshop operations and cooperation in this block, within the research of the time study of the preparation of calculations this block is taken as a whole, where individual operations will not be specified due to their diversity.

Handling and packaging: Within the production of parts, it is also necessary to take into account the nonproduction costs of internal handling during production and subsequently the time required for the final inspection and packaging of already finished parts.

Transport: Shipping costs are considered optional in this block depending on prior agreement with the customer. For the presented research, the collection of finished parts by the customer at the headquarters of the supplier is considered.

Margins: The last and most fundamental point that affects the tender calculation is the determination of the amount of the supplier's profit when processing the ordered order. The amount is determined individually according to the key parameters of the business and competitive strategy of the company. 


\subsection{Online web application the Aurendi}

The Aurendi online web application is a tool for engineering companies engaged in the production of sheet metal parts and welded constructions. The Aurendi has been designed for a specific area of tender calculations to achieve higher price accuracy while increasing efficiency. The application includes regularly updated price databases of metallurgical materials made of steel, stainless steel, and aluminum, and also contains price databases of purchase items, such as fasteners. The application is developed to reflect the diversification of each company's machine portfolio. Therefore, each user can add their own machine park to the technical library of the application and use only this data. The application also allows technical comparison of different technologies and their suitability and usability for each specific demand.

Through the focus of the application on the creation of tender calculations, it is necessary to emphasize its delimitation from classic technological calculations to the reliable execution of which are crucial higher technical knowledge of the user in the given technologies. For this reason, the application offers maximum technical support and all calculation blocks are designed to calculate the minute allowance for partial technical tasks. The user-designed time allowances for each work operation are evaluated in the target rate of the performed action depending on the input data that the user fills in when the application is started for the first time. The input data that must be entered by the user include the company's hourly rate, hourly rates for submachines, a profit setting system depending on the quantity levels, and the business model with regard to the competitive environment. The application environment and its advantageous affordability for small and medium-sized enterprises also bring new sales and marketing channels for suppliers of metallurgical and fasteners in the manufacturing industry. Through the automatically generated inquiry form sent to the partner companies, suppliers can immediately respond to the inquiry sent in the initial tender of their potential customers. The system is able to determine the necessary data for calculation from drawing documentation in .dxf format based on multi-parametric analysis by inserting a drawing documentation file into the application environment. The cloud implementation of the project guarantees the usability of the system regardless of the user's location. Other advantages of the application include a large number of partial functionalities that simplify the user's work with tender calculations. The output of the application is the cost and sales prices calculated for each partial work operation and the purchased item in the required quantity levels of each calculated item. The user can generate the given price output in .pdf or .xlsx formats and combine the calculated data within their own settings.

\subsection{Experimental part}

The study is performed on 15 type drawings of sheet metal parts of welded constructions. The drawings were carefully selected to account for all key blocks. All drawing documentation is properly marked for retrospective inspection. The research is focused on the comparison of two methodological approaches and the resulting amount of time savings when using the automated method of calculating tender calculations through the online web application the Aurendi. Surveys are performed by time deduction for each individual calculation performed. A 3-minute pause was established between calculating each drawing. First, the calculation was performed by a conventional method, only using basic office supplies and printed drawing documentation. The conventional procedure was performed according to the research of the established calculation methodology. Table 1 shows the resulting costs for the production of parts and the time required to calculate the calculation. The second part of the table shows the time values read when working with the Aurendi, at the same time the price value for each calculated part is given. The most important point in the table is the percentage calculation of time savings when creating a tender calculation using an automated methodology with respect to price formation in a conventional manner. 
Table 1 Collected data of time savings and costs

\begin{tabular}{|c|c|c|c|c|c|}
\hline \multirow{2}{*}{$\begin{array}{l}\text { Drawing } \\
\text { number }\end{array}$} & \multicolumn{2}{|c|}{ Conventional procedure } & \multicolumn{2}{|c|}{ Automated procedure by Aurendi } & \multirow[t]{2}{*}{ Time saving [\%] } \\
\hline & $\begin{array}{l}\text { Time required } \\
\text { [min] }\end{array}$ & Final cost [CZK] & $\begin{array}{l}\text { Time required } \\
\text { [min] }\end{array}$ & Final cost $[\mathrm{CZK}]$ & \\
\hline 301-00-001-01 & $12: 09.35$ & $4,430.00$ & $5: 45.58$ & $4,166.86$ & 52.58 \\
\hline $301-00-008-01$ & $7: 28.17$ & 980.00 & $4: 02.47$ & 881.16 & 45.84 \\
\hline $301-00-014-00$ & $8: 16.24$ & $1,240.00$ & $4: 35.05$ & $1,342.86$ & 44.58 \\
\hline $301-00-015-01$ & $11: 07.53$ & $2,550.00$ & $5: 14.06$ & $2,289.99$ & 52.97 \\
\hline $301-02-000-00$ & $13: 02.18$ & $3,550.00$ & $6: 15.31$ & $3,745.27$ & 52.00 \\
\hline $301-03-000-01$ & $13: 53.04$ & $3,450.00$ & $6: 41.39$ & $3,621.45$ & 51.79 \\
\hline $301-03-002-00$ & $6: 46.24$ & 850.00 & $3: 26.14$ & 756.63 & 49.25 \\
\hline $302-00-017-00$ & $11: 48.57$ & $2,400.00$ & $5: 31.21$ & $2,341.65$ & 53.26 \\
\hline 302-00-033-02 & $7: 22.06$ & 720.00 & $3: 56.48$ & 767.99 & 46.44 \\
\hline 302-03-007-02 & $17: 44.56$ & $5,950.00$ & $7: 54.34$ & $5,578.36$ & 55.44 \\
\hline 303-04-002-01 & $11: 03.42$ & $1,460.00$ & $5: 25.31$ & $1,369.63$ & 50.95 \\
\hline 303-04-005-01 & $10: 26.08$ & $1,330.00$ & $5: 15.03$ & $1,226.29$ & 49.68 \\
\hline $303-06-000-00$ & $13: 27.06$ & $3,280.00$ & $6: 31.06$ & $3,054.77$ & 51.54 \\
\hline $303-06-002-00$ & $8: 36.21$ & 710.00 & $4: 25.16$ & 615.43 & 48.63 \\
\hline 304-00-023-02 & 7:59.06 & $1,220.00$ & $4: 28.32$ & $1,331.83$ & 43.95 \\
\hline \multicolumn{5}{|c|}{ The resulting average time saving [\%] } & 49.93 \\
\hline
\end{tabular}

\section{RESULTS AND DISCUSSION}

The result and the answer for the research question is almost $50 \%$-time savings when using the Aurendi web application. This conclusion can be assessed as justified. The Aurendi provides its own database of regularly updated prices of metallurgical materials, so the person responsible for tender calculation does not have to communicate with suppliers during each calculation. Another key point is the automation of the calculation when dividing the material, including the recommendation of the most suitable layout on the sheet format. The calculation of this block is only a vague estimate in the conventional methodological approach without the use of software for a laser or other material cutting machine. By using specialized software, an accurate calculation is available, but again, the time for preparing the offer calculation increases many times over. It is also necessary to take into account the need for the employee responsible for creating calculations to be trained in the use of the given software. A further reduction in time can be stated on the basis of Aurendi's own methodological approach. The application of our own methodology increases efficiency and accuracy while reducing the risk of omitting a partial workshop adjustment in the calculation. At first glance, the resulting calculation is more accurate than the calculation performed by the conventional method. The accuracy and precision of the calculation are not the subject of examination of the submitted final work and for this reason, the feedback of real production costs will not be evaluated with respect to the calculation of the tender calculation. This feedback will be evaluated when setting technical parameters and algorithms in the application itself in specific companies. The study is performed using a prototype of the Aurendi calculation application and it is necessary to state another possible increase in time savings when completing product development leading to maximizing efficiency at work and optimizing the user environment. 


\section{CONCLUSION}

This paper aims to compare the methodological approaches to the formation of tender calculation in engineering companies oriented on the production of metal sheet parts and welded constructions. The subject of the research is to determine the percentage of time savings using the automated methodology offered by the calculation tool, the Aurendi on-line application, in comparison with the conventional approach to the calculation used in practice.

\section{ACKNOWLEDGEMENTS}

The work was supported by the specific university research of the Ministry of Education, Youth and Sports of the Czech Republic in VSB - Technical University of Ostrava No. SP2021/43 and SP2021/71.

\section{REFERENCES}

[1] SLÁČALA, J., ŠPAČKOVÁ, H., MENŠÍK, M., SVOBODOVÁ, P., BARČÁK, T. Use of robotic manipulation systems in automation of forging processes. In: METAL 2020: conference proceedings: reviewed version: 29th International Conference on Metallurgy and Materials. Brno, Czech Republic: Tanger, 2020. ISBN 978-80-8729497-0

[2] KUTÁČ, J., KUTÁČ, T, BESTA, P., ŠVECOVÁ, E. Choosing of appropriate operative evidence in company producing tubular products. In: METAL 2018: conference proceedings: reviewed version: 27th International Conference on Metallurgy and Materials. Brno, Czech Republic: Tanger, 2018, s. 2024-2028. ISBN 978-8087294-84-0

[3] WIERDA, L. Cost Information Tools for Designers. Delft, The Netherlands: Delft University Press, 1990.

[4] GALLAGHER, C.C., KNIGHT, W.A. Group Technology, Production Methods in Manufacturing, Chichester, England: Ellis Horwood, 1986.

[5] GEIGER, T.S., DILTS, D.M.: Automated design-to-cost: Integrating costing into the design decision. ComputerAided Design, 1996, vol. 28, no. 6-7, pp. 423-438.

[6] STAUB-FRENCH, S., FISCHER, M., KUNZ, J., PAULSON, B.: A generic feature-driven activity-based cost estimation process. Advanced Engineering Informatics. 2003, vol. 17, pp. 23-39.

[7] VERLINDEN, B., J.R. DUFLOU, P. COLLIN a D. CATTRYSSE. Cost estimation for sheet metal parts using multiple regression and artificial neural networks: A case study. International Journal of Production Economics [online]. 2008, vol. 111, no. 2, pp. 484-492. [cit. 2021-5-15]. ISSN 09255273. Available from: https://doi.org/10.1016/.j.ipe.2007.02.004.

[8] SHEHAB, E.M., ABDALLA, H.S.: Manufacturing cost modelling for concurrent product development. Robotics and Computer-Integrated Manufacturing. [online]. 2001, vol. 17, no.4, pp. 341-353. Available from: https://doi.org/10.1016/S0736-5845(01)00009-6.

[9] JUREČKA, V. Mikroekonomie. 3., aktualizované a rozšířené vyd. Praha: Grada Publishing, 2018. ISBN 978-80271-2126-7.

[10] LIPOVSKÁ, H. Moderní ekonomie. 1. vyd. Praha: Grada Publishing, 2017. ISBN 978-80271-9609-8.

[11] MIKOLÁŠ, Z. Jak zvýšit konkurenceschopnost podniku - Konkurenční dynamika a potenciál podnikání. 1. vyd. Praha: Grada Publishing, 2005. ISBN 80-247-1277-6. 